\title{
WATER STORAGE CHANGES IN UPPER SOIL LAYERS IN DIFFERENT FOREST HABITATS
}

\author{
Rafał Stasik', Barbara Kęsicka' \\ 1 Institute of Land Improvement, Environmental Development and Geodesy, Faculty of Environmental \\ Engineering and Spatial Management, Poznań University of Life Sciences, Piątkowska 94, 60-649 Poznań, \\ Poland, e-mail: stasikr@up.poznan.pl, basia.kesicka@gmail.com
}

Received: 2017.07.07

Accepted: 2017.08.15

Published: 2017.11.01

\begin{abstract}
Trends in changes of water storage in upper soil layers were analyzed. The observations were carried out from 2002 to 2016 hydrological year in a small forest catchment in the district of Siemianice Forest Experimental Farm (LZD). The samples were taken from the upper soil layer of profiles located in different forest habitats, both at the beginning and at the end of hydrological half-years. Water storage was evaluated separately for two layers at the depths of 0-15 cm and 15-100 cm. Changes in water storage determined using the Mann-Kendall test were found to indicate multi-year trends. Results of the study are inconclusive. There were no statistically significant long-term trends in water storage changes in soil profiles in moist mixed broadleaved and coniferous forest and also in the soil profiles of fresh habitats. However, it is worth noting that statistically significant downward trends of water storage in two soil profiles located in ash alder swamp forest and moist broadleaved forest were observed. To some degree, they can be accounted for by long-term downward trends of groundwater levels in the area.
\end{abstract}

Keywords: water storage, forest habitats, forest soils water management

\section{INTRODUCTION}

The soil water dynamics as well as groundwater levels are determined mainly by precipitation and air temperature (Hodnett et al. 1995, Komisarek et al. 2008, Liberacki, Szafrański 2013, Yeh et al. 2006). Climate changes observed in the last decades can lead to deterioration of water management [Grajewski et al. 2013, Kędziora et al. 2014]. The increase in air temperature can increase the transpiration and thus decrease the water content and lower the groundwater levels. It is worth noting that water resources of Wielkopolska lowland are the poorest in Poland. The results of recent studies carried out in a small forest catchment located in Wielkopolska lowland indicated a downward trends in groundwater levels in all forest types [Stasik et al. 2016], however, not all decreases observed were statistically significant. As a continuation of this recent investigation the aim of this study was to analyze multi-year water storage changes in different forest stands.

\section{STUDY AREA, MATERIALS AND METHODS}

The study was carried out in a small forest located in Marianka Siemiańska forest district (Rakowski Ditch catchment, which is denoted as G-ditch on the map). The district belongs to the Siemianice Forest Experimental Farm (LZD). According to Regional geography of Poland [Kondracki 2011] the forests of LZD Siemianice are located in Wieruszowska Plateau. This area is located in the South Wielkopolska Lowland and makes its southern frontier (Fig. 1).

In terms of hydrography, the object is a part of Pomianka River catchment area, which is a left-bank tributary of the Prosna River. Marian- 


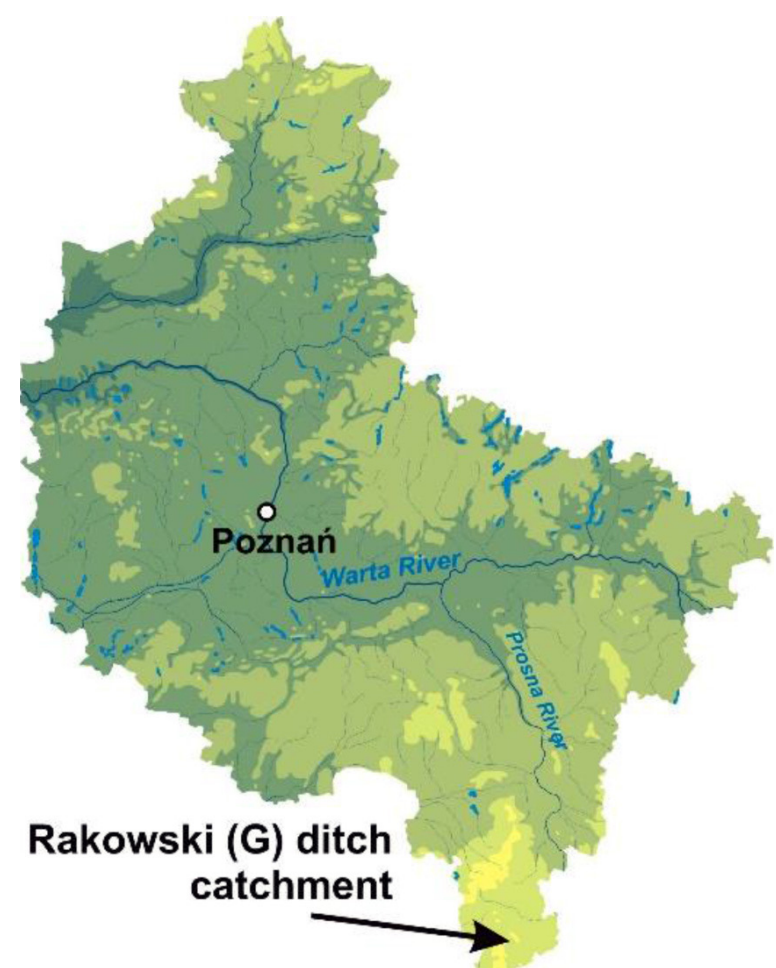

Fig. 1. Location of Siemianice Forest Experimental Farm against Wielkopolska map

ka Siemiańska forest district is located in northeast part of Oleśnicka Plain mesoregion, Silesia nature woodland country, according to the 2010 nature-forestry regionalization [Zielony, Kliczkowska 2012]. Swampy forest stands (about 51\% of wooded area) dominate in the catchment area. Moist forest stands have also a significant share $(31 \%)$ in the wooded catchment area. The total fresh forest stands occupy $18 \%$ of the area.

The data on the soil and forest type at particular sites were taken from the soil-forest site maps contained in Soil-Habitat Assessment of LZD Siemianice (1999) as well as from the forest database (www.bdl.lasy.gov.pl).

Nine soil profiles representing individual forest stands were chosen for analyses. The data were collected for the soil profiles: 1.3 and 2.12 located in ash-alder swamp forest (OlJ), 2.8 in moist broadleaved forest (Lw), 2.11 in moist mixed broadleaved forest (LMw), 3.12 and 4.2 in moist mixed coniferous forest (BMw), 4.8 and 5.5 in fresh mixed broadleaved forest (LMśw), and G3.9 located in fresh mixed coniferous forest (BMśw). Permeable formations - mostly loose sands, loamy sands and sandy silt were found to dominate in the analyzed soil profiles $(1.3,2.8$, 2.11, 3.9, 4.2, 4.8. 5.5), although loamy silt and sandy loam $(2.12,3.12)$ were also present.
The procedure of the study included systematic sampling of undisturbed monolithic soil samples. Three samples were taken from each genetic layer of each individual soil profile (Fig. 2 ), in the end of winter (April) and summer (October) hydrological half-year. Water storage was evaluated for two separate layers: $0-15 \mathrm{~cm}$ and $15-100 \mathrm{~cm}$ in each soil profile. The water content in the aeration zone was determined using the gravimetric method, while the water content in the saturated zone was taken as equal to porosity. Daily measurements of precipitation sums and air temperature, were carried out at LZD Siemianice. The above data were taken from 2002-2016 hydrological period.

Non-parametric statistical Mann-Kendall test was used to analyze the changes in water storage trends in soil profiles as well as the trends in the changes in precipitation and air temperature. The Mann-Kendall test is defined as [Hirsch et al. 1982, Gilbert 1987, Maksymiuk et al. 2008].:

$$
\mathrm{S}=\sum_{\mathrm{k}=1}^{\mathrm{n}-1} \sum_{\mathrm{j}=\mathrm{k}+1}^{\mathrm{n}} \operatorname{sgn}\left(\mathrm{x}_{\mathrm{j}}-\mathrm{x}_{\mathrm{k}}\right)
$$

where:

$$
\begin{aligned}
& \operatorname{sgn}\left(x_{j}-x_{k}\right)=\left\{\begin{array}{l}
1 \text { if }\left(x_{j}-x_{k}\right)>0 \\
0 \text { if }\left(x_{j}-x_{k}\right)=0 \\
-1 \text { if }\left(x_{j}-x_{k}\right)<0
\end{array}\right. \\
& \{x 1, x 2, \ldots, x n\}-\text { data points }
\end{aligned}
$$

If $\mathrm{S}$ value is close to zero it indicates no-trend hypothesis, $\mathrm{S}$ value significantly higher than zero indicates an upward trend, meanwhile $\mathrm{S}$ value significantly lower than zero suggests a downward trend. The tests were made separately for winter and summer hydrological half-years, because water capacity shows seasonal changes.

When $\mathrm{Zs}>\mathrm{Zkr}$ than the trend is statistically significant; $Z \mathrm{kr}=1.95$ when the confidence level is $\alpha=0.05$. The value of $Z s$ is calculated from the following formula:

$$
\begin{aligned}
& \mathrm{Z}=\frac{\mathrm{S}-1}{\sqrt{\operatorname{Var}(\mathrm{S})}} \text { when: } \mathrm{S}>0 \\
& \text { and } \mathrm{Z}=\frac{\mathrm{S}+1}{\sqrt{\operatorname{Var}(\mathrm{S})}} \text { when: } \mathrm{S}<0
\end{aligned}
$$

For the time series $n>10$, the variation is calculated from the following formula:

$$
\operatorname{Var}(S)=\frac{1}{18} \mathrm{n}(\mathrm{n}-1)(2 \mathrm{n}+5)
$$




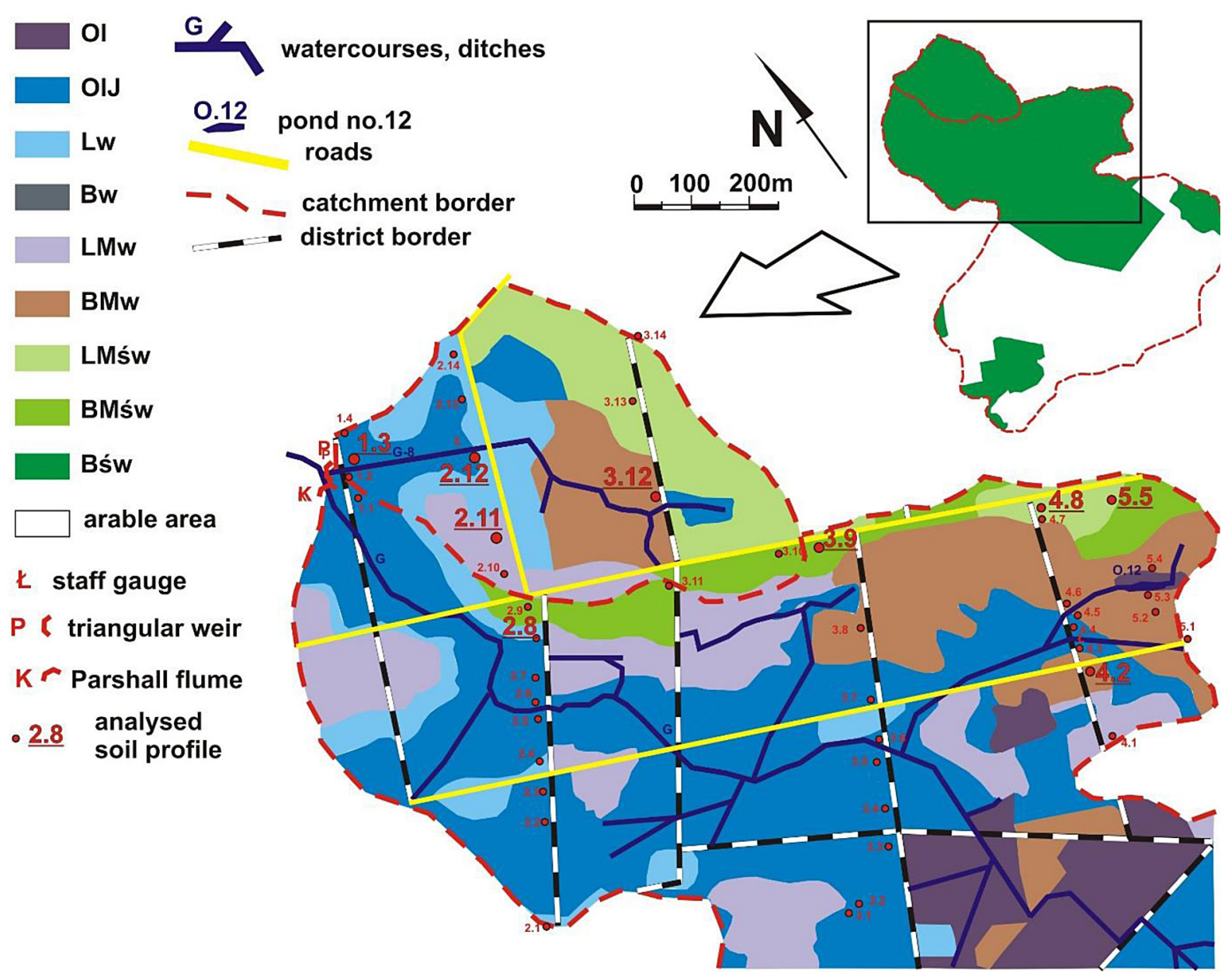

Figure 2. Forest habitat maps of analyzed parts of $\mathrm{G}$ ditch with soil profile location. Descriptions of forest site types: Ol - alder carr forest, OlJ - ash-alder swamp forest, Lw - moist broadleaved forest, LMw - moist mixed broadleaved forest, BMw - moist mixed coniferous forest, LMśw - fresh mixed broadleaved forest,

BMśw - fresh mixed coniferous forest, Bśw - fresh coniferous forest Lśw - fresh broadleaved forest

\section{RESULTS AND DISCUSSION}

Average air temperatures and precipitation sums in the period of 2002-2016 hydrological years indicate changeability of weather conditions (tab. 1). Very cold and very warm as well as very dry and extremely moist half-years were observed. The results of Mann-Kendal statistical calculation for the air temperature suggest a slight increase in the average half-year temperatures, however the $\mathrm{S}$ value is not statistically significant. The S describing the amount of precipitation suggests a slight decrease in precipitation sums in the winter half-year and their slight increase in the summer half-year. However, both $\mathrm{S}$ values are not statistically significant.

The values and linear trends indicate a decrease in water storage in the $0-15 \mathrm{~cm}$ layer for soil profile 2.12 located in ash alder swamp forest and 2.8 in moist broadleaved forest, measured in
April in the end of winter half-year in 2002-2016 hydrological years (Fig. 3A). This decrease is also confirmed by statistically significant $\mathrm{S}$ values for these soil profiles, $S=65$ and $S=-78$ respectively. No trend in water storage changes was observed for profile 1.3 in ash alder swamp forest. The $\mathrm{S}=+41$ for moist mixed broadleaved forest (2.11 profile) also indicates statistically significant decreasing trend in the water storage in the upper layer. Both soil profiles 3.12 and 4.2 in moist mixed coniferous forest show slightly downward trends, but they are not statistically significant (Fig. 3B). In the soil profiles in the fresh mixed broadleaved and coniferous forest, no trend in water storage changes in the upper layers is observed (Fig. 3C).

Figure 4 presents the result of water storage in the deeper layer, $15-100 \mathrm{~cm}$, of the soil profiles measured also in April in the end of winter halfyear in 2002-2016 hydrological years. Statistical- 
Table 1. Average temperatures (T) and thermal classification by Lorenz (by Czernecki and Miętus 2011), precipitation $(\mathrm{P})$ and their classification according to relative precipitation index RPI (Tomaszewska 1994) as well as S value for winter and summer hydrological half-years in analyzed period 2002-2016

\begin{tabular}{|c|c|c|c|c|c|c|c|c|}
\hline \multirow{3}{*}{$\begin{array}{l}\text { Hyd. } \\
\text { year }\end{array}$} & \multicolumn{4}{|c|}{ Winter half-year (November-April) } & \multicolumn{4}{|c|}{ Summer half-year (May-October) } \\
\hline & \multicolumn{2}{|r|}{$T$} & \multicolumn{2}{|r|}{$P$} & \multicolumn{2}{|r|}{$\mathrm{T}$} & \multicolumn{2}{|c|}{$P$} \\
\hline & {$\left[{ }^{\circ} \mathrm{C}\right]$} & classification & {$[\mathrm{mm}]$} & classification & {$\left[{ }^{\circ} \mathrm{C}\right]$} & classification & {$[\mathrm{mm}]$} & classification \\
\hline 2002 & +2.1 & normal & 213 & average & +15.6 & normal & 325 & average \\
\hline 2003 & +0.1 & very cold & 150 & very dry & +15.4 & normal & 371 & average \\
\hline 2004 & +3.2 & slightly warm & 273 & very moist & +15.0 & slightly cold & 2535 & very dry \\
\hline 2005 & +0.9 & slightly cold & 223 & average & +16.3 & slightly warm & 237 & very dry \\
\hline 2006 & +0.2 & very cold & 371 & extremely moist & +16.4 & warm & 262 & very dry \\
\hline 2007 & +2.4 & normal & 252 & moist & +15.1 & normal & 301 & dry \\
\hline 2008 & +2.7 & normal & 252 & moist & +15.4 & normal & 244 & very dry \\
\hline 2009 & +1.2 & slightly cold & 184 & dry & +14.8 & slightly cold & 441 & moist \\
\hline 2010 & +0.5 & cold & 243 & moist & +14.4 & cold & 563 & extremely moist \\
\hline 2011 & +2.2 & normal & 229 & average & +16.2 & slightly warm & 270 & dry \\
\hline 2012 & +1.9 & normal & 175 & dry & +15.7 & normal & 427 & moist \\
\hline 2013 & +0.0 & very cold & 258 & moist & +15.5 & normal & 453 & very moist \\
\hline 2014 & +4.5 & very warm & 169 & dry & +16.1 & slightly warm & 368 & average \\
\hline 2015 & +3.5 & slightly warm & 156 & very dry & +16.4 & warm & 182 & very dry \\
\hline 2016 & +3.8 & warm & 256 & moist & +16.3 & slightly warm & 357 & average \\
\hline $\mathrm{S}$ & & +27 & & -11 & & +21 & & +13 \\
\hline
\end{tabular}

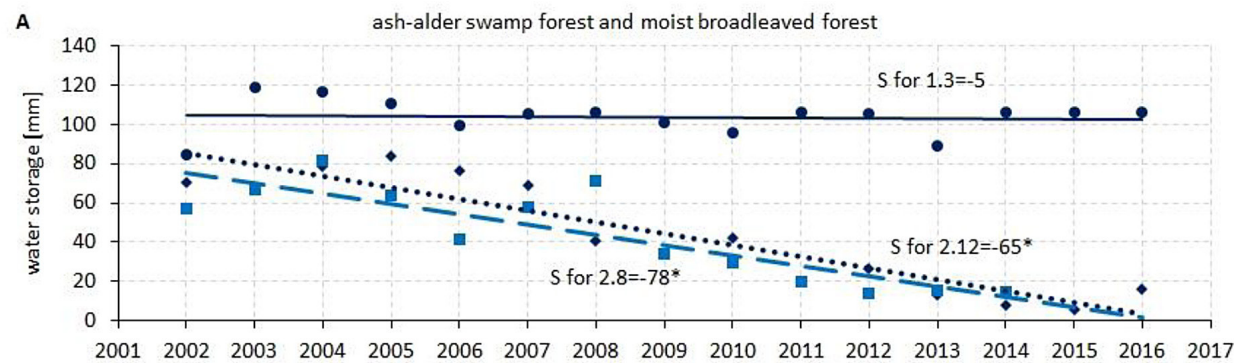

- 1.3 OlJ $\quad 2.12 \mathrm{OU} \quad 2.8 \mathrm{Lw}$ — linear for $1.3 \quad \ldots$. linear for $2.12 \quad$ — linear for 2.8

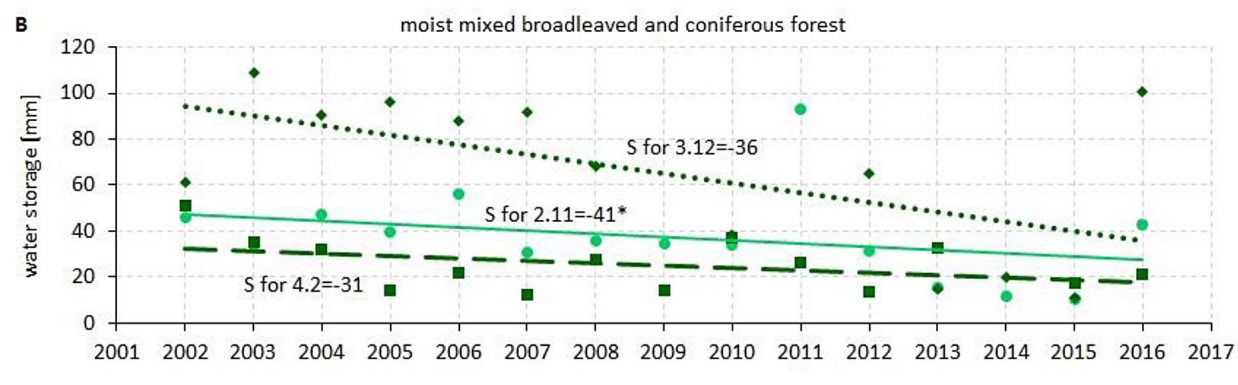

- $2.11 \mathrm{LMw}$ - $3.12 \mathrm{BMw}$ - $4.2 \mathrm{BMw}$ —linear for $2.11 \ldots$. linear for 3.12 — - linear for 4.2

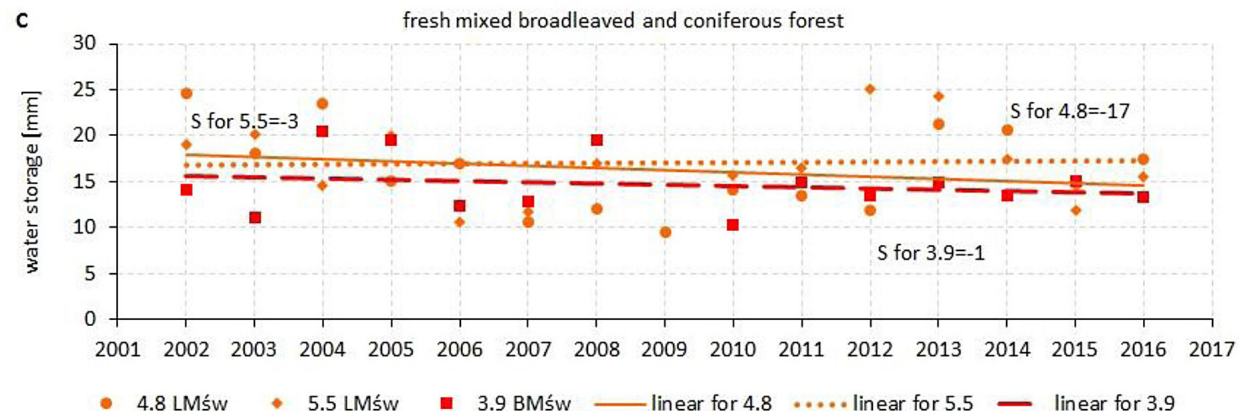

Figure 3. Water storage in the layer $0-15 \mathrm{~cm}$ of the analyzed soil profiles, linear trends in its changes and $\mathrm{S}$ value (* - statistically significant), measured in April in 2002-2016 hydrological years. Description of forest site types abbreviation the same as in Figure 2. 
ly significant downward trends of water storage is observed in the soil profiles 2.12 and $2.8(-55$ and -74 respectively), similarly as it is observed in the layer $0-15 \mathrm{~cm}$ (Fig. 4A). It is worth noting that the upward trend is observed in profile 1.3 for the deeper layer $15-100 \mathrm{~cm}$, however the trend is not statistically significant. Upward trends of water storage are also observed in the fresh habitats in profiles 3.9 and 5.5 (Fig. 4C). The S value for profile 5.5 located in the fresh mixed broadleaved forest is statistically significant $(S=+45)$.

Similar downward trends in water storage in the layer $0-15 \mathrm{~cm}$ in soil profiles in swampy habitats are observed also in the end of summer half years (Fig. 5). The trend at profile 2.12, located in the moist broadleaved forest is statistically significant, meanwhile the other trends at profiles 1.3 (slightly increased) and 2.12 located in the ash-alder swamp forest are insignificant (Fig. 5A). There are no statistically significant trends in water storage changes in the layer $0-15 \mathrm{~cm}$ in the soil profiles located in the moist mixed broadleaved and coniferous forest (Fig. 5B). It is worth noting that in the fresh mixed habitats slightly upward trends are observed at profiles 3.9 and 4.8 , however, the trends are not statistically significant (Fig. 5C).

Figure 6 presenting water storage changes in the layer $15-100 \mathrm{~cm}$ measured in the end of summer half-year also indicates a statistically significant ( $\mathrm{S}=-57$ ) downward trend in water storage change in soil profile 2.8 in the moist broadleaved forest. The trend in profile 2.12 in the ash-alder swamp forest (Fig. 6A) is also downward and statistically significant $(S=-49)$. Statistically insignificant downward ( $\mathrm{S}=-21$ for profile 2.11) and
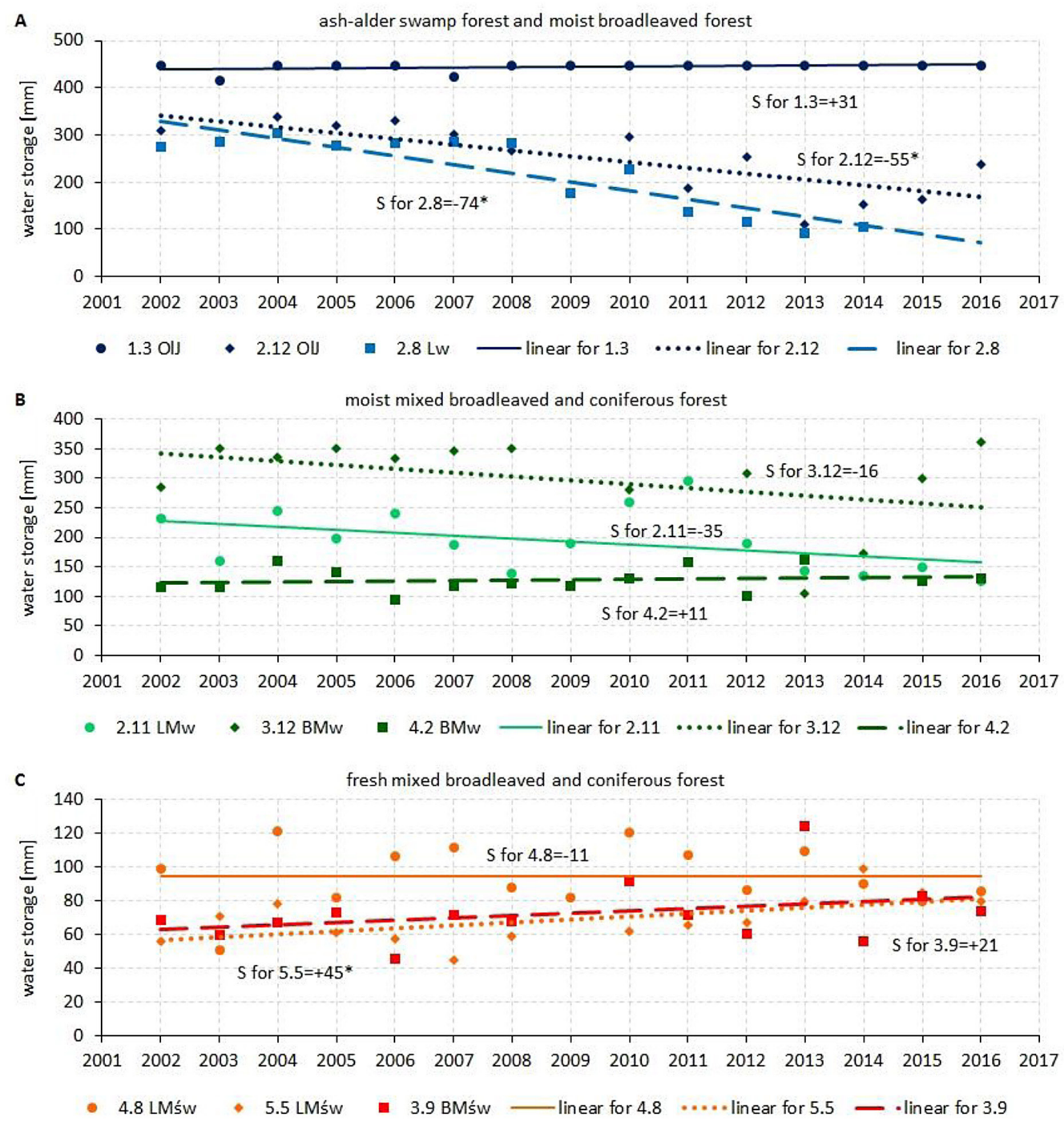

Figure 4. Water storage in the layer $15-100 \mathrm{~cm}$ of the analyzed soil profiles, linear trends in its changes and $\mathrm{S}$ value $(*$ - statistically significant), measured in April in 2002-2016 hydrological years. 

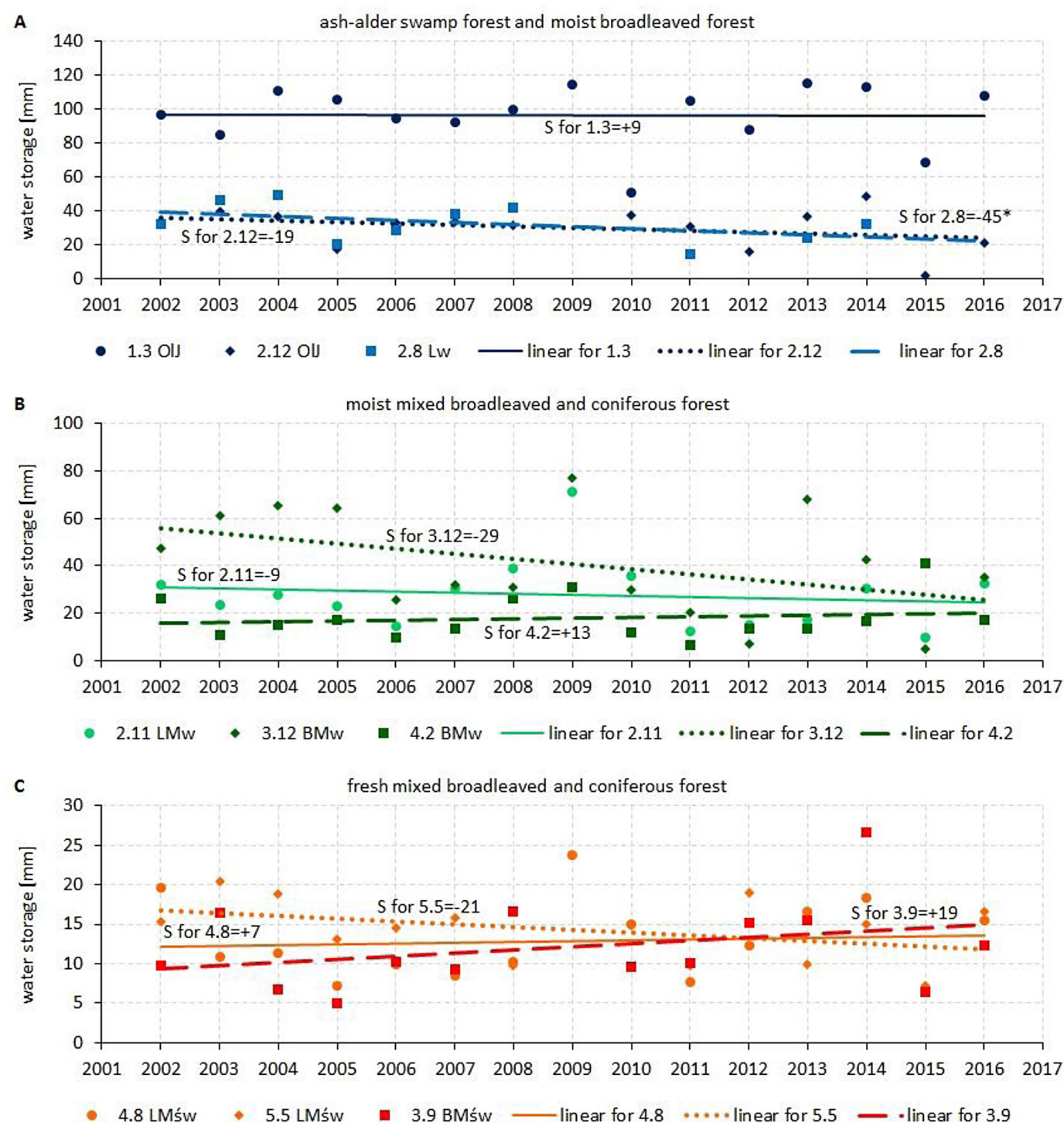

Figure 5. Water storage in the layer $0-15 \mathrm{~cm}$ of the analyzed soil profiles, linear trends in its changes and $\mathrm{S}$ value $(*$ - statistically significant), measured in October in 2002-2016 hydrological years.

upward $(\mathrm{S}=+11$ for profile 3.12 and $\mathrm{S}=+37$ for profile 4.2 ) trends are observed in the moist mixed broadleaved and coniferous forest (Fig. 6B).

In the soil profiles located in the fresh mixed broadleaved and coniferous forest (Fig. 6C) statistically insignificant, but slightly upward trends in water storage were observed.

\section{CONCLUSIONS}

The results of the study performed are inconclusive. There are no statistically significant longterm trends in water storage changes in the moist mixed broadleaved and coniferous forest. However, in the soil profile located in the moist mixed broadleaved forest, a downward trend of water storage in the layer $0-15 \mathrm{~cm}$ is observed. Also in the soil profiles in the fresh habitats no significant trends are observed. Upward trend of water storage is observed only in the soil profile of fresh mixed coniferous forest in the layer $15-100 \mathrm{~cm}$.

However, it is worth noting that statistically significant downward trends of water storage in two soil profiles located in the ash alder swamp forest and moist broadleaved forest are observed, in both layers $0-15 \mathrm{~cm}$ and $15-100 \mathrm{~cm}$ at the end of winter half-year. It can be affected by longterm downward trends in groundwater levels observed in this area (Stasik et al. 2016). Such downward trends have also been reported by Grajewski et al. (2013). 

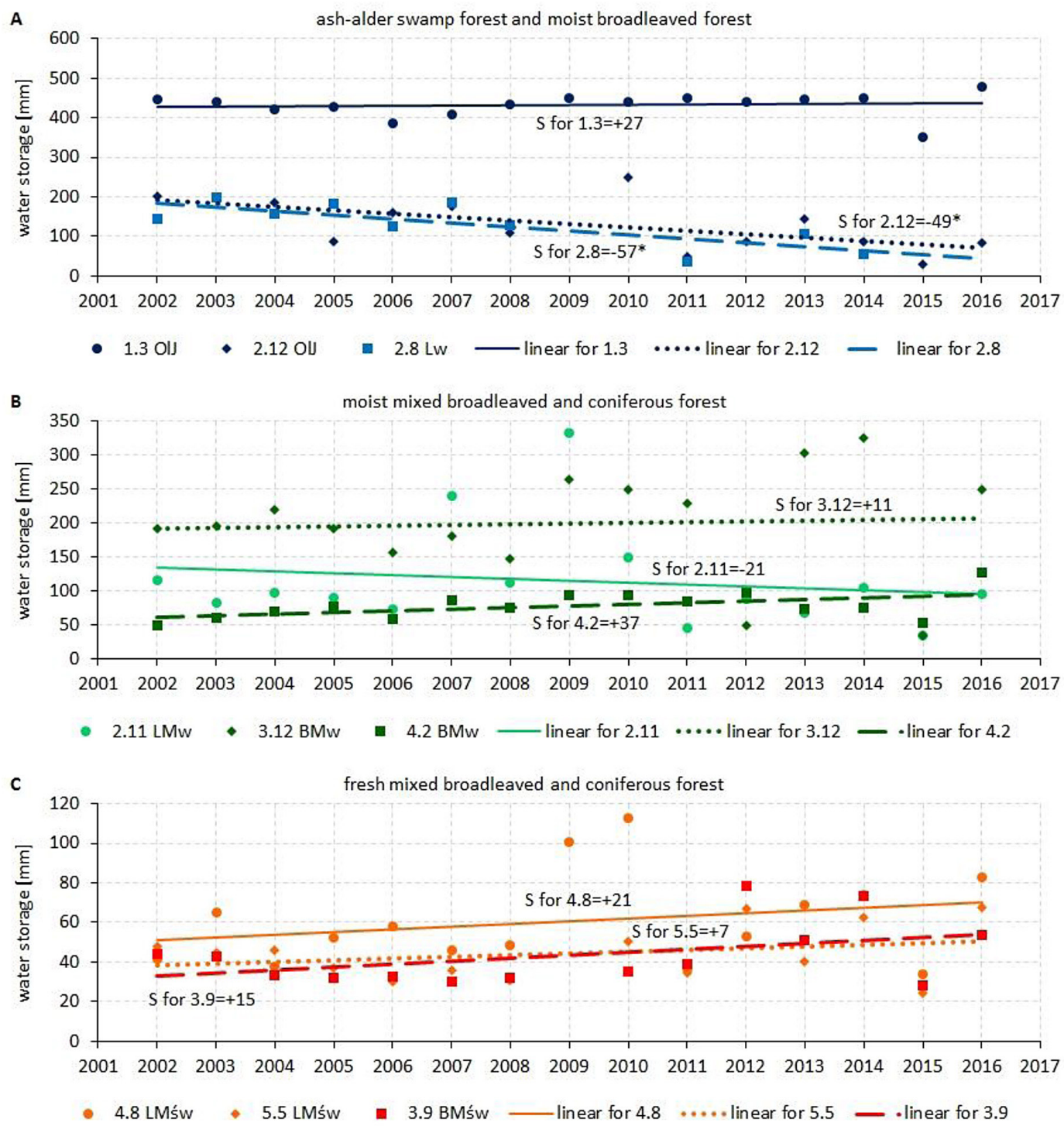

Figure 6. Water storage in the layer $15-100 \mathrm{~cm}$ at the analyzed soil profiles, linear trends in its changes and S value $(*$ - statistically significant), measured in October in 2002-2016 hydrological years.

\section{REFERENCES}

1. Czernecki B., Miętus M. 2011. Comparison of thermal classification for selected regions of Poland, 201-233 [in Polish].

2. Gilbert R. O. 1987. Statistical method for environmental pollution monitoring, chapt. 16.4 MannKendall Test, 208-217.

3. Grajewski, S. (2013). Thermal conditions in the Zielonka Forest in the period 1987-2008. Nauka Przyroda Technologie, 7(1), 9 [in Polish].

4. Grajewski S., Miler A. T., Krysztofiak-Kaniewska A. 2013. Changes of groundwater levels in the Zielonka Forest in period 1970-2009, Annual Set The Environment Protection (Rocznik Ochrony Środowiska), 15(cz. 2), 1594-1611 [in Polish].

5. Hirsch R. M., Slack J. R., Smith R. A. 1982. Techniques of trend analysis for monthly water quality data, Water Resources Researches, vol. 18, no. 1, 107-121.

6. Hodnett M. G., Da Silva L. P., Da Rocha H. R., Senna R. C. (1995). Seasonal soil water storage changes beneath central Amazonian rainforest and pasture. Journal of hydrology, 170(1-4), 233-254.

7. Kędziora A., Kępińska-Kasprzak M., Kowalczak P., Kundziewicz Z. W., Miler A. T., Pierzgalski E., Tokarczyk T. 2014. Risks resulting from water shortages, Nauka 2014/1, 149-172 [in Polish].

8. Komisarek J., Kozłowski M., Wiatrowska K. 2008. Deficiencies of plant available water in soil catena of undulating ground moraine. Nauka Przyroda Technologie, 2(3), 23.

9. Kondracki J. 2011. Regional geography of Poland. Wydawnictwo Naukowe PWN Warszawa, 444 ss. [in Polish].

10. Liberacki D., Szafrański C. 2013. Trends in level of 
the groundwater table in the selected catchments in the Zielonka Forest. Annual Set The Environment Protection (Rocznik Ochrony Środowiska), 15, 2425-2436 [in Polish].

11. Maksymiuk A., Furmańczyk K., Ignar S., Krupa J, Okruszko T. 2008. Analysis of climatic and hydrologic parameters variability in the Biebrza River basin, Przegląd naukowy Inżynieria i Kształtowanie Środowiska nr 3 (41), 59-68.

12. Soil-Habitat Assessment of LZD Siemianice. 1999. Zakład Usług Ekologicznych i Urządzeniowo Leśnych Poznań [in Polish].

13. Stasik R., Korytowski M., Liberacki D. 2016. Trends in groundwater level changes in small forest catchments of Wielkopolska. Journal of Ecological Engineering, 17(4), 99-106.
14. Szafrański Cz. 1993. Water management of rich relief area and needs of its reclamation. Rocz. AR Poznań. Rostr. Nauk. 244 ss [in Polish].

15. Tomaszewska T. 1994. Atmospheric droughts in the last four decades. In Mat. konf. XXV Zjazdu Agrometeorologów, Olsztyn-Mierki (169-178) [in Polish].

16. Yeh P. J. F., Swenson S. C., Famiglietti J. S., Rodell M. (2006). Remote sensing of groundwater storage changes in Illinois using the Gravity Recovery and Climate Experiment (GRACE). Water Resources Research, 42(12).

17. Zielony R., Kliczkowska A. 2012. Natural-forest regionalization of Poland 2010. Centrum Informacyjne Lasów Państwowych. Warszawa, 356 ss [in Polish].

18. www.bdl.lasy.gov.pl/portal/mapy 